\title{
Effects of sodium chloride salting and substitution with potassium chloride on whey expulsion of Cheddar cheese
}

\author{
Y. Lu and D. J. McMahon ${ }^{1}$ \\ Western Dairy Center, Utah State University, Logan 84322-8700
}

\begin{abstract}
A challenge in manufacturing reduced-sodium cheese is that whey expulsion after salting decreases when less salt is applied. Our objectives were (1) to determine whether changing the salting method would increase whey syneresis when making a lower sodium cheese and (2) to better understand factors contributing to salt-induced curd syneresis. Unsalted milled Cheddar curds were salted using different salting intervals ( 5 or $10 \mathrm{~min}$ ), different salting levels $(20,25$, or $30 \mathrm{~g} / \mathrm{kg}$ ), different numbers of applications when using only 20 $\mathrm{g} / \mathrm{kg}$ salt $(1,2$, or 3 applications), and salting with the equivalent of $30 \mathrm{~g} / \mathrm{kg} \mathrm{NaCl}$ using a 2:1 molar ratio of $\mathrm{NaCl}$ and $\mathrm{KCl}$. Whey from these curds was collected every 5 or 10 min until 30 or 40 min after the start of salting, and curds were subsequently pressed for 3 h. Additional trials were conducted in which salted milled Cheddar cheese curd was immersed at $22^{\circ} \mathrm{C}$ for $6 \mathrm{~h}$ in various solutions to determine how milled curd pieces respond to different levels of salt and Ca. The use of 10-min intervals delayed whey syneresis without influencing total whey expulsion or cheese composition after pressing. Lowering the salt level reduced whey expulsion, resulting in cheeses with higher moisture and slightly lower $\mathrm{pH}$. Adding salt faster did not increase whey expulsion in reduced-salt cheese. Partial substitution with $\mathrm{KCl}$ restored the extent of whey expulsion. When salted milled curd was immersed in a $30 \mathrm{~g} / \mathrm{L}$ salt solution, there was a net influx of salt solution into the curd and curd weight increased. When curd was immersed in $60 \mathrm{~g} / \mathrm{L}$ salt solution, a contraction of curd occurred. Curd shrinkage was more pronounced as the salt solution concentration was increased to 90 and $120 \mathrm{~g} / \mathrm{L}$. Increasing the Ca concentration in test solutions (such that both serum and total $\mathrm{Ca}$ in the curd increased) also promoted curd contraction, resulting in lower curd moisture and $\mathrm{pH}$ and less weight gain by the curd. The proportion of $\mathrm{Ca}$ in the curd that was bound to the para-casein protein matrix changed with
\end{abstract}

Received July 10, 2014.

Accepted October 2, 2014.

${ }^{1}$ Corresponding author: Donald.mcmahon@usu.edu the Ca content of the test solution. Compared with test solutions containing $10 \mathrm{~g} / \mathrm{L} \mathrm{Ca}$, at low Ca levels (i.e., 1 and $5 \mathrm{~g} / \mathrm{L}$ ) the proportion of bound $\mathrm{Ca}$ was lower, whereas at $20 \mathrm{~g} / \mathrm{L} \mathrm{Ca}$, the proportion of bound $\mathrm{Ca}$ was higher. Both $\mathrm{Ca}$ and salt concentration influence the physicochemical properties of the protein matrix such that at low concentrations the curd expands, whereas at high concentrations the curd contracts and expels whey.

Key words: cheese, syneresis, salt, potassium

\section{INTRODUCTION}

In cheese manufacture, the process of whey being expelled out of curd is called syneresis (Pearse and Mackinlay, 1989). The rate and extent of syneresis strongly affects mechanical handling during the subsequent cheese-making steps, loss of fat and protein in whey, cheese moisture, ongoing acidification, and proteolysis, and therefore strongly influences cheese composition and quality (Daviau et al., 2000; Dejmek and Walstra, 2004; Everard et al., 2008). Generally, salting of cheese curd promotes syneresis and results in a decreased moisture level (Kindstedt et al., 1992; Pastorino et al., 2003a; Agarwal et al., 2008). With this expulsion of whey, up to $50 \%$ of the salt added to curd can be lost, depending on the salting level (Grummer et al., 2013). Reduced-salt cheeses exhibit less syneresis after salting (Johnson et al., 2009) (and therefore have lower salt losses) and have high moisture compared with curd salted at the normal level (Schroeder et al., 1988; Fox et al., 2000; Guinee and Fox, 2004).

When dry salt is applied to milled cheese curd, salt dissolves slowly in moisture on the curd surfaces and forms a thin layer of concentrated salt solution. Osmotic pressure produced by this concentration gradient between the curd surface and the interior of the curd particle provides a driving force for salt and water diffusion (Georgakis, 1973; Guerts et al., 1974; Resmini et al., 1974). Sodium and chloride ions and water molecules can respond by diffusing through the serum phase contained within the protein matrix of curd particles to restore equilibrium (Guinee, 2004; Guinee and Fox, 2004). Based upon the chemical environment, this 
can result in a net movement of water from the curd particles, which is observed as whey syneresis.

Protein solubility plays a role in water movement in cheese by promoting protein matrix shrinkage or expansion (Guo and Kindstedt, 1995; Paulson et al., 1998; Pastorino et al., 2003a; McMahon et al., 2009; Fucà et al., 2012). Sodium and other monovalent ions at low concentration can have a salting-in effect, which causes increased protein solubility and expansion of the protein matrix. At high concentration, a salting-out effect reduces protein solubility, resulting in contraction and dehydration of the protein matrix (Guo et al., 1997; Paulson et al., 1998; Guinee and Fox, 2004; McMahon et al., 2005).

Calcium content of the cheese curd also affects the extent of whey syneresis after salting. Paulson et al. (1998) reported that salting can stop whey syneresis if the curd has a low Ca content. We have also observed that adding $\mathrm{CaCl}_{2}$ as part of the salting can promote syneresis but only when the curd has been manufactured to have a low Ca content (unpublished data). Likewise, injecting $\mathrm{Ca}$ into a low-Ca cheese causes shrinkage of the cheese block with concomitant syneresis (Pastorino et al., 2003b). In contrast, adding Ca to milk before cheese manufacture can reduce syneresis of cheese curd (Fagan et al., 2007; Geng et al., 2011). At high Ca levels, cheese develops a more cross-linked, rigid, and less hydrated protein network (Pastorino et al., 2003b; McMahon et al., 2005).

It has been suggested that partial replacement of $\mathrm{NaCl}$ with $\mathrm{KCl}$ can be used to produce reduced-sodium Cheddar cheese without adversely affecting cheese quality (Lindsay et al., 1982; Fitzgerald and Buckley, 1985; Grummer et al., 2013). Our objective was to determine whether changing the salting method would increase whey syneresis after salting when making a lower sodium cheese. To better understand the factors contributing to salt-induced curd syneresis, a curd immersion test was used to study contraction of the milled curds as influenced by salt and calcium levels.

\section{MATERIALS AND METHODS}

\section{Curd Salting}

Unsalted milled Cheddar cheese curd (410 to $420 \mathrm{~g} /$ $\mathrm{kg}$ moisture, $\mathrm{pH}$ 5.4) was obtained from Aggie Creamery (Utah State University, Logan) and divided into $3-\mathrm{kg}$ batches (in the first of 3 trials, $1.5-\mathrm{kg}$ batches were used). Each experiment was conducted in triplicate with fresh curd obtained on separate days for each replicate. Cheese curds were manufactured following the method of Rogers et al. (2010) and milled at pH 5.4 .
Curd $\left(34^{\circ} \mathrm{C}\right)$ was placed in a plastic container (with lid) and salted using sodium chloride (TFC H.G. Blending salt; Morton Salt Inc., Chicago, IL) and potassium chloride (J. T. Baker, Phillipsburg, NJ) as described in Table 1 . The blending salt used is recommended by the manufacturer for salting of Cheddar cheese curd because of its uniform particle size, cubical shape, and the addition of a water-soluble anticaking agent. Whey was collected periodically for about $30 \mathrm{~min}$ and the curd reweighed. Curd was then placed in an 18.5-cm-diameter, round, porous plastic hoop. Hoops were placed in a vertical press and pressed at $100 \mathrm{kPa}$ for $3 \mathrm{~h}$ at room temperature $\left(\sim 20^{\circ} \mathrm{C}\right)$. After pressing, the cheese sample was collected for chemical analysis.

\section{Curd Immersion}

A "whey" stock solution for curd immersion tests was prepared from whey that was collected during the cheddaring stage of cheese manufacture after curd $\mathrm{pH}$ had decreased to $<6.1$. It was then heated to $72^{\circ} \mathrm{C}$ for $15 \mathrm{~s}$, cooled to $4^{\circ} \mathrm{C}, 0.2 \mathrm{~g} / \mathrm{L}$ sodium azide added, and the whey stored at $4^{\circ} \mathrm{C}$. Before use it was diluted $1: 1$ with deionized water (to prevent precipitation of calcium phosphate when additional calcium was added) and then sodium chloride (Morton Salt Inc.) and calcium chloride (J. T. Baker) were added to prepare the test solutions. Salted Cheddar cheese curd $(405 \mathrm{~g} / \mathrm{kg}$ moisture, $\mathrm{pH}$ 5.4) and unsalted Cheddar cheese curd (409 g/kg moisture, $\mathrm{pH} 5.3$ ) were obtained from Aggie Creamery and tested for response to various $\mathrm{Ca}$ and $\mathrm{Na}$ levels, respectively.

Different Salt Levels. Pieces of unsalted milled Cheddar curd $(\sim 100 \mathrm{~g})$ were accurately weighed, placed into plastic container that were filled with $300 \mathrm{~g}$ of test solutions containing 30,60, 90, or $120 \mathrm{~g} / \mathrm{L} \mathrm{NaCl}$, supplemented with $6 \mathrm{~g} / \mathrm{L} \mathrm{Ca}$ [we had previously found that levels of 5 to $11 \mathrm{~g} / \mathrm{L} \mathrm{Ca}$ in this test solution maintain the insoluble Ca to solids ratio (Insol Ca/solids) in cheese curd], adjusted with $\mathrm{NaOH}$ to 5.4 (i.e., the $\mathrm{pH}$ of salted curd), and then sealed and kept at $22^{\circ} \mathrm{C}$. After storing for $6 \mathrm{~h}$, the curd was removed and excess moisture was removed by rolling the curd over a paper tissue; then, the curd was reweighed and tested for moisture, $\mathrm{pH}$, and salt. Adjusted weight change (AWC) of curd was calculated as total weight change minus calculated weight of $\mathrm{NaCl}$ that had diffused into cheese.

Different Ca Levels. Aliquots of $100 \mathrm{~g} \pm 0.3 \mathrm{~g}$ of salted milled curd were accurately weighed and then immersed in $300 \mathrm{~g}$ of test solutions per liter containing $15 \mathrm{~g}$ of $\mathrm{NaCl}$ (to reduce the diffusion of sodium between cheese serum and test solutions), and 1, 5, 10, or $20 \mathrm{~g}$ of $\mathrm{Ca}$ (added as $\mathrm{CaCl}_{2}$ ) with $\mathrm{pH}$ adjusted with $\mathrm{NaOH}$ 
Table 1. Different salting methods of unsalted Cheddar cheese curd at $20^{\circ} \mathrm{C}$

\begin{tabular}{llcl}
\hline Cheese Na reduction & $\begin{array}{l}\text { Salt }{ }^{1} \text { added per } \\
\text { kg of curd }\end{array}$ & $\begin{array}{c}\text { No. of } \\
\text { applications }{ }^{2}\end{array}$ & $\begin{array}{c}\text { Interval } \\
(\mathrm{min})\end{array}$ \\
\hline No reduction & $30 \mathrm{~g}$ of $\mathrm{NaCl}$ & 3 & 5 or 10 \\
0,17 , or $33 \%$ reduction & $30,25,20 \mathrm{~g}$ of NaCl & 3 & 5 \\
$33 \%$ reduction & $20 \mathrm{~g}$ of $\mathrm{NaCl}$ & 1,2, or 3 & 5 \\
$33 \%$ reduction & $20 \mathrm{~g}$ of $\mathrm{NaCl}$ and $12.7 \mathrm{~g}$ of $\mathrm{KCl}$ & 3 & 5 \\
\hline${ }^{1} \mathrm{NaCl}$ or molar equivalent. & & \\
${ }^{2}$ Total salt divided evenly over number of applications.
\end{tabular}

to 5.3 (i.e., the $\mathrm{pH}$ of unsalted curd after weighing), in plastic containers at $22^{\circ} \mathrm{C}$. After 6 or $18 \mathrm{~h}$, containers were opened, visual observations made on condition of cheese, cheese reweighed, and weight of remaining test solution measured. Cheese was analyzed for moisture, $\mathrm{pH}, \mathrm{Na}$, serum $\mathrm{Ca}$, and total $\mathrm{Ca}$ before and after immersion.

\section{Chemical Analysis}

Cheese $\mathrm{pH}$ was measured using a $\mathrm{pH}$ electrode (Hanna Instruments, Ann Arbor, MI) after stomaching 20 $\mathrm{g}$ of grated cheese and $10 \mathrm{~g}$ of deionized water at 260 rpm for $1 \mathrm{~min}$ in a Stomacher 400 (Seward, London, UK). Moisture was analyzed by weight loss using a microwave oven (Smart System 5, CEM Corp., Indian Trail, NC) at $100 \%$ power, with an endpoint setting of $<0.5 \mathrm{mg}$ of weight change over $10 \mathrm{~s}$. Salt content was measured by stomaching $5 \mathrm{~g}$ of grated cheese with 98.2 $\mathrm{g}$ of deionized water, filtering the slurry through Whatman \#1 filter paper, and analyzing the filtrate using a chloride analyzer (model 926; Corning Scientific, Medfield, MA). Calcium and Na content was measured by ashing $50 \mathrm{~g}$ of grated cheese at $500^{\circ} \mathrm{C}$ for $24 \mathrm{~h}$ in a muffle furnace (model 550-126, Fisher Scientific, Hanover Park, IL), and mineral analysis was performed by inductively coupled plasma spectroscopy (Analab, Fulton, IL). Serum Ca was determined by blending $5 \mathrm{~g}$ of grated cheese with $50 \mathrm{~g}$ of deionized water in the stomacher. After sitting for $10 \mathrm{~min}$, the slurry was filtered through Whatman \#42 filter paper, and the filtrate was sent for mineral analysis. Mineral concentration of test solutions before cheese immersion was also measured after filtering through Whatman \#42 filter paper. All measurements were made in triplicate. Salt-in-moisture $(\mathbf{S} / \mathbf{M})$ was calculated as salt divided by moisture plus salt.

\section{Statistical Analysis}

All data were analyzed for statistical significance at 95\% level using PROC GLM or PROC MIXED function in SAS software (version 9.3; SAS Institute Inc., Cary,
NC). Whey expulsion experiments were conducted using a randomized block design, with data square-root transformed to meet normality and homoscedasticity assumptions before significance testing. Curd immersion with different salt levels was conducted using a completely randomized design. Two-way ANOVA was used to analyze the effect of different Ca levels and storage time in curd immersed with different Ca levels. Linear regression was performed to investigate the effect of salt concentration on AWC, Ca concentration on Insol $\mathrm{Ca} /$ solids, and Insol $\mathrm{Ca} /$ solids on cheese weight change. Significance was declared at $P<0.05$ and trends at $0.05<P<0.10$. Post hoc means comparisons were made based on $P$-values $(\alpha=0.05)$ using TukeyKramer adjustment to obtain differences of least mean squares.

\section{RESULTS}

\section{Curd Salting}

Salting Interval. Cheese curd had an initial moisture content of $420 \mathrm{~g} / \mathrm{kg}$. After salting with $30 \mathrm{~g}$ of $\mathrm{NaCl}$ per $\mathrm{kg}$ of curd using 5-min or 10-min intervals followed by $6 \mathrm{~h}$ of pressing, we detected no significant difference $(P>0.4)$ in cheese composition caused by different salting intervals. Mean $( \pm \mathrm{SE})$ cheese composition was as follows: moisture $362( \pm 1) \mathrm{g} / \mathrm{kg}$, salt $18.6( \pm 0.3) \mathrm{g} /$ $\mathrm{kg}, \mathrm{S} / \mathrm{M} 48.9( \pm 0.7) \mathrm{g} / \mathrm{kg}$, and $\mathrm{pH} 5.22( \pm 0.01)$.

When the typical level of salt was added to curd (i.e., $30 \mathrm{~g} / \mathrm{kg})$, very little whey $(\sim 2 \%)$ was expelled before the second salt addition at both 5-min and 10-min intervals (Figure 1). Applying the salt at 5-min intervals caused faster syneresis than using 10-min intervals because salt was added at a faster rate. A surge in syneresis occurred at 15 and 25 min for salting using 5 and 10-min intervals, respectively. Consequently, when measured at 20 and 25 min after the start of salting, the amount of expelled whey differed significantly $(P<$ 0.001). Amounts of whey expelled at $20 \mathrm{~min}$ after the third salting (i.e., 30 min after start of salting for 5 -min intervals and $40 \mathrm{~min}$ for 10-min intervals) were similar, with a trend $(P=0.054)$ for slightly more whey expulsion when using the 5 -min intervals than the 10-min 


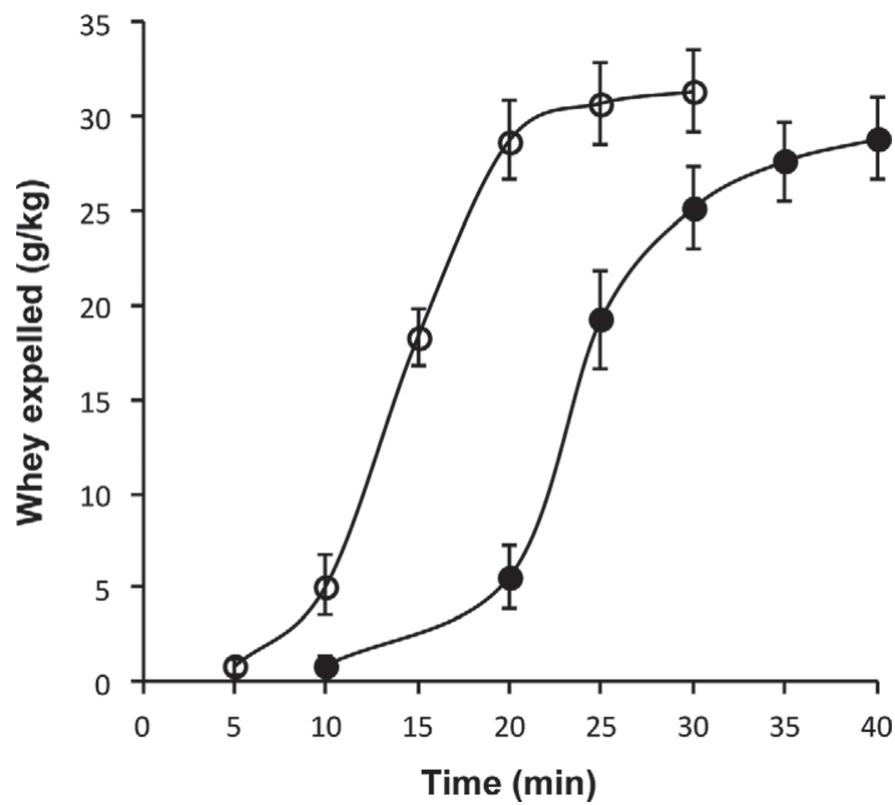

Figure 1. Whey expulsion over time from the first salt application of milled Cheddar curd with $30 \mathrm{~g} / \mathrm{kg}$ of salt added over 3 applications using either 5-min $(\bigcirc)$ or 10-min $(\bullet)$ intervals. Error bars represent standard errors.

intervals. Based on the asymptotic shape of the curves in Figure 1, it appears that given sufficient time, the 10-min interval treatment would reach the same level of whey expulsion as the 5-min interval treatment.

As mentioned above, the shape of whey expulsion curves indicated that the last portion of whey was expelled more slowly with salting at 10-min intervals (Figure 1). In the first $15 \mathrm{~min}$ after the third salting (i.e., $25 \mathrm{~min}$ after start of salting for 5 -min intervals and 35 min for 10-min intervals), curds salted at 5-min intervals expelled $39.3 \%$ of whey, whereas those salted at 10-min intervals expelled only $34.5 \%$ of whey. By 20 min after the third salt application, when using 5-min interval, the amount of whey being expelled reached a plateau.

Salting Level. Unsalted curds had moisture of about $410 \mathrm{~g} / \mathrm{kg}$ and $\mathrm{pH}$ of 5.4. Decreasing salting levels from 30 to $20 \mathrm{~g} / \mathrm{kg}$ yielded cheese with higher moisture $(P$

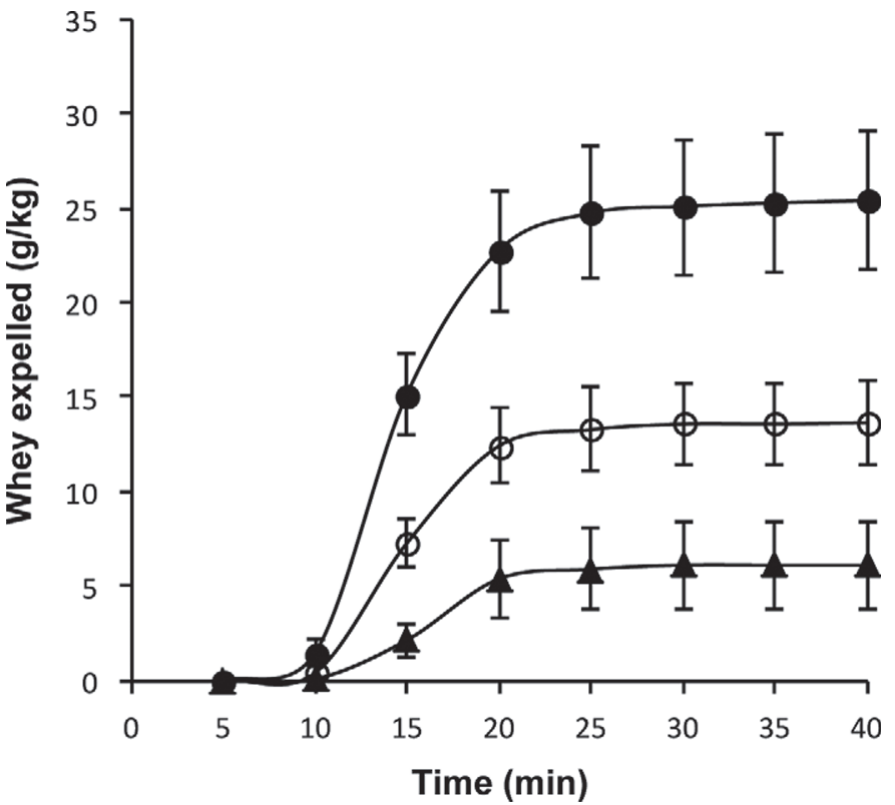

Figure 2. Whey expulsion over time from the first salt application of milled Cheddar curd with $30 \mathrm{~g} / \mathrm{kg}(\bullet), 25 \mathrm{~g} / \mathrm{kg}(\bigcirc)$, or $20 \mathrm{~g} / \mathrm{kg}$ of salt $(\boldsymbol{\Lambda})$ added over 3 applications using 5-min intervals. Error bars represent standard errors.

$<0.001)$ and lower $\mathrm{pH}(P<0.006)$, as well as having lower salt and $\mathrm{S} / \mathrm{M}(P<0.001$; Table 2$)$. This follows the expected pattern of less whey expulsion when less salt is added to curd and a concomitant increase in residual lactose so that more fermentation to lactic acid occurs. As already shown, whey expulsion occurred primarily after the third salting (Figure 2). By 10 min after all the salt had been applied, the extent of syneresis reached $84.3,90.8$, and $90.5 \%$ of total whey expelled for curd salted with 20, 25, and $30 \mathrm{~g} / \mathrm{kg}$, respectively. By 15 min after third salting, virtually no further expulsion of whey occurred. Lowering salt by one-third (i.e., to $20 \mathrm{~g} / \mathrm{kg}$ ) reduced mean syneresis before pressing by $80 \%$ from $25.4 \mathrm{~g} / \mathrm{kg}$ to $6.1 \mathrm{~g} / \mathrm{kg}$.

Salting Application. Applying $20 \mathrm{~g} / \mathrm{kg}$ salt all at once or divided over 2 applications had no significant effect $(P \geq 0.2)$ on resultant cheese composition with mean $( \pm \mathrm{SE})$ values of moisture $375( \pm 1) \mathrm{g} / \mathrm{kg}$, salt

Table 2. Composition of cheese after salting with different levels of salt $(20,25$, and $30 \mathrm{~g} / \mathrm{kg})$ over 3 applications, 5 min apart, and pressed for $3 \mathrm{~h}$ at $22^{\circ} \mathrm{C}$

\begin{tabular}{lcccc}
\hline $\begin{array}{l}\text { Salting level } \\
(\mathrm{g} / \mathrm{kg})\end{array}$ & $\begin{array}{c}\text { Moisture } \\
(\mathrm{g} / \mathrm{kg})\end{array}$ & $\begin{array}{c}\text { Salt } \\
(\mathrm{g} / \mathrm{kg})\end{array}$ & $\begin{array}{c}\mathrm{S} / \mathrm{M}^{1} \\
(\mathrm{~g} / \mathrm{kg})\end{array}$ & $\mathrm{pH}$ \\
\hline 20 & $370^{\mathrm{a}}$ & $15.4^{\mathrm{a}}$ & $40.0^{\mathrm{a}}$ & $5.2^{\mathrm{a}}$ \\
25 & $359^{\mathrm{b}}$ & $17.6^{\mathrm{b}}$ & $46.7^{\mathrm{b}}$ & $5.3^{\mathrm{b}}$ \\
30 & $356^{\mathrm{b}}$ & $18.9^{\mathrm{c}}$ & $50.4^{\mathrm{c}}$ & $5.3^{\mathrm{b}}$ \\
\hline
\end{tabular}

${ }^{\mathrm{a}-\mathrm{c}}$ Means within a column with the same superscript letter were not significantly different.

${ }^{1} \mathrm{~S} / \mathrm{M}=$ salt-in-moisture. 


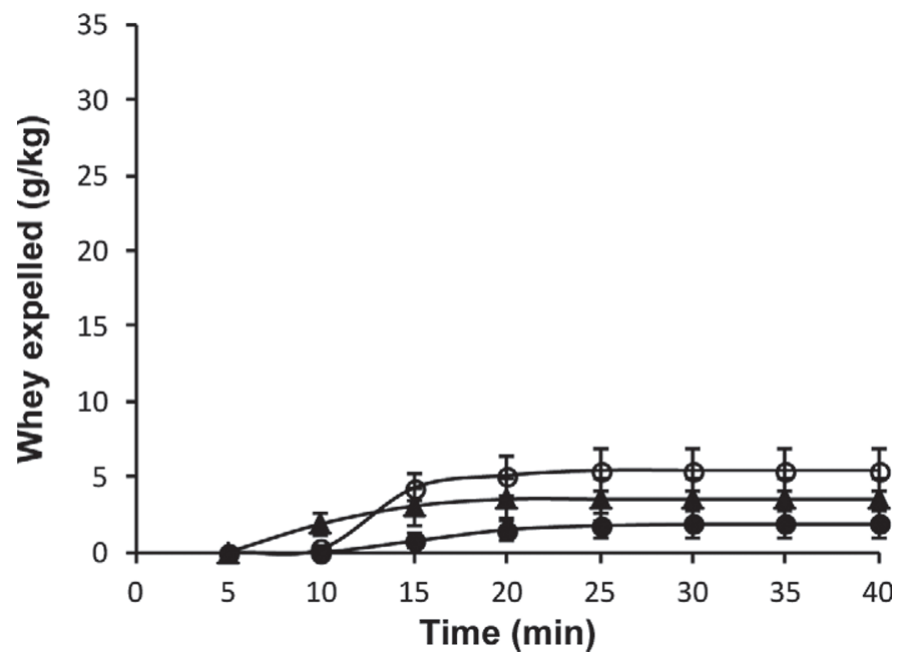

Figure 3. Whey expulsion over time from the first salt application of milled Cheddar curd with $20 \mathrm{~g} / \mathrm{kg}$ of salt added over 1 ( $\mathbf{\Delta}), 2$ $(\bigcirc)$, or $3(\bullet)$ applications using 5-min intervals. Error bars represent standard errors.

$16.5( \pm 0.2) \mathrm{g} / \mathrm{kg}, \mathrm{S} / \mathrm{M} 42.0( \pm 0.5) \mathrm{g} / \mathrm{kg}$, and $\mathrm{pH} 5.25$ $( \pm 0.01)$. Applying salt using only one application caused faster, but no more, syneresis compared with using 2 or 3 applications (Figure 3). Probably, using only one salt application causes a rapid increase in salt concentration and diffusion across the curd exterior, resulting in faster initial whey expulsion that causes more salt being lost initially before diffusing into the curd. We detected a trend $(P=0.08)$ for 2 applications to cause slightly more whey expulsion than 1 application, whereas significantly more whey was expelled with 2 applications compared with 3 after $15 \min (P<0.001)$ and before pressing $(P<0.003)$ (Table 3$)$.

Salt Substitution. Whey expulsion and cheese moisture were the same when $\mathrm{KCl}$ was used to replace $10 \mathrm{~g} / \mathrm{kg} \mathrm{NaCl}$ and $30 \mathrm{~g} / \mathrm{kg} \mathrm{NaCl}$ was used $(P>0.05)$. This agrees with McMahon et al. (2014) that molar substitution of $\mathrm{KCl}$ for $\mathrm{NaCl}$ does not influence cheese moisture content. Similar results were found by others (Fitzgerald and Buckley, 1985; Katsiari et al., 1998; Ayyash et al., 2011; Grummer et al., 2012, 2013). Just

Table 3. Whey expulsion $(\mathrm{g} / \mathrm{kg})$ at 15 and 20 min after the start of addition of $20 \mathrm{~g} / \mathrm{kg}$ of salt and before pressing when using 1,2 , or 3 applications 5 min apart

\begin{tabular}{lccc}
\hline $\begin{array}{l}\text { Application } \\
\text { (no.) }\end{array}$ & $15 \mathrm{~min}$ & $20 \mathrm{~min}$ & $\begin{array}{c}\text { Before } \\
\text { pressing }\end{array}$ \\
\hline 1 & $3.1^{\mathrm{a}}$ & $3.5^{\mathrm{ab}}$ & $3.5^{\mathrm{ab}}$ \\
2 & $4.3^{\mathrm{a}}$ & $5.1^{\mathrm{a}}$ & $5.4^{\mathrm{a}}$ \\
3 & $0.7^{\mathrm{b}}$ & $1.5^{\mathrm{b}}$ & $1.8^{\mathrm{b}}$ \\
\hline
\end{tabular}

${ }^{\mathrm{a}, \mathrm{b}}$ Means within a column with the same superscript letter were not significantly different, $\alpha=0.05$.

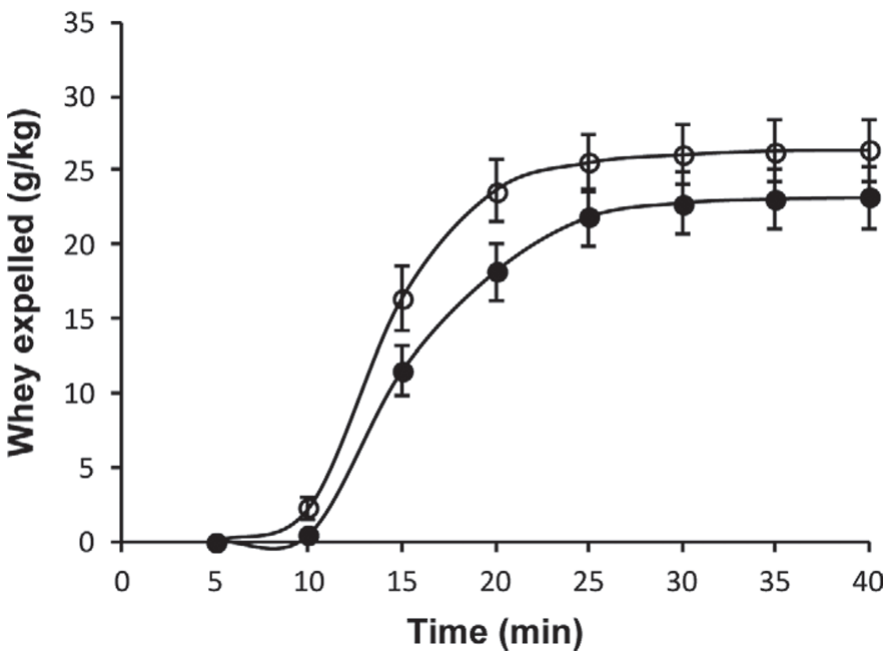

Figure 4. Whey expulsion over time from the first salt application of milled Cheddar curd with $30 \mathrm{~g} / \mathrm{kg}$ of salt $(\bullet)$ or a salt mixture consisting of a 2:1 molar ratio of $\mathrm{NaCl}$ and $\mathrm{KCl}(\mathrm{O})$ added over 3 applications using 5-min intervals. Error bars represent standard errors.

as when salting with $30 \mathrm{~g} / \mathrm{kg} \mathrm{NaCl}$, the $\mathrm{KCl}-\mathrm{NaCl}$ mixture caused little whey expulsion before the third application (Figure 4). Extent of syneresis was slightly faster at $15 \mathrm{~min}(P<0.001)$ and $20 \mathrm{~min}(P=0.016)$ when using the $\mathrm{KCl}-\mathrm{NaCl}$ mixture, but there was no difference in amount of whey expelled before pressing $(P=0.19)$

\section{Curd Immersion}

Immersion with Different Salt Levels. After immersion of unsalted curd in test solutions for $6 \mathrm{~h}$, both curd weight $\left(\mathrm{R}^{2}=0.99, P<0.001\right)$ and AWC $\left(\mathrm{R}^{2}=0.99, P<0.001\right)$ were inversely proportional to salt concentration in the test solutions (Table 4 and Figure 5). At low salt concentration $(30 \mathrm{~g} / \mathrm{L})$, the curd increased in weight, as previously shown in Ragusano cheese (Fucà et al., 2012). We detected a 2.4\% AWC (i.e., increase in cheese weight caused by absorption of water, corrected for salt diffusion into the curd), resulting in an increase in moisture content of the curd from 409 to $419 \mathrm{~g} / \mathrm{kg}$.

At high salt concentrations in the test solutions (90 and $120 \mathrm{~g} / \mathrm{L}$ ), cheese weight decreased, indicating curd shrinkage and whey expulsion (Table 4). Using AWC, the crossover between curd expansion and shrinkage was calculated to occur at a salt concentration of 57 $\mathrm{g} / \mathrm{L}$. Only marginal changes in AWC occurred for curd immersed in the $60 \mathrm{~g} / \mathrm{L}$ salt solution, with no significant difference in moisture content.

Moisture $(P<0.001)$ and $\mathrm{pH}(P=0.025)$ of curd were significantly influenced by the 6 -h immersion in test solutions of $30,60,90$, or $120 \mathrm{~g} / \mathrm{L} \mathrm{NaCl}$ (to which 
Table 4. Weight change and composition of curd after $6 \mathrm{~h}$ of immersion in solutions of 30,60, 90, or $120 \mathrm{~g} / \mathrm{L}$ of $\mathrm{NaCl}$ and $6 \mathrm{~g} / \mathrm{L}$ of $\mathrm{Ca}$ at $22^{\circ} \mathrm{C}$

\begin{tabular}{lcccc}
\hline & \multicolumn{4}{c}{ NaCl level $(\mathrm{g} / \mathrm{L})$} \\
\cline { 2 - 5 } Variable $^{1}$ & 30 & 60 & 90 & 120 \\
\hline Moisture $(\mathrm{g} / \mathrm{kg})$ & $419^{\mathrm{d}^{*}}$ & $402^{\mathrm{c}}$ & $381^{\mathrm{b}^{*}}$ & $370^{\mathrm{a}^{*}}$ \\
Salt $(\mathrm{g} / \mathrm{kg})$ & $13^{\mathrm{a}}$ & $19^{\mathrm{b}}$ & $25^{\mathrm{c}}$ & $29^{\mathrm{d}}$ \\
S/M (g/kg) & $30^{\mathrm{a}}$ & $44^{\mathrm{b}}$ & $61^{\mathrm{c}}$ & $72^{\mathrm{d}}$ \\
$\mathrm{pH}$ & $5.08^{\mathrm{b}^{*}}$ & $5.10^{\mathrm{b}^{*}}$ & $5.07^{\mathrm{ab}^{*}}$ & $5.05^{\mathrm{a}^{*}}$ \\
Weight change (\%) & $4.4^{\mathrm{d}}$ & $1.4^{\mathrm{c}}$ & $-1.4^{\mathrm{b}}$ & $-4.0^{\mathrm{a}}$ \\
AWC $(\%)$ & $3.0^{\mathrm{d}}$ & $-0.5^{\mathrm{c}}$ & $-3.9^{\mathrm{b}}$ & $-6.7^{\mathrm{a}}$ \\
\hline
\end{tabular}

$\overline{\mathrm{a}-\mathrm{d}}$ Means within rows with the same letter were not significantly different, $\alpha=0.05$.

${ }^{1} \mathrm{~S} / \mathrm{M}$ = salt-in-moisture; $\mathrm{AWC}=$ adjusted weight change as a function of water absorption; that is, gross weight change - salt level of cheese.

*Means were significantly different from Cheddar cheese curd before immersion, $\alpha=0.05$.

$6 \mathrm{~g} / \mathrm{L}$ Ca had been added; Table 4). The decrease in $\mathrm{pH}$ was considered a result of continued lactose fermentation by starter culture bacteria, as would occur during cheese pressing for an equivalent time. Curd moisture was inversely proportional to salt level of test solutions $\left(\mathrm{R}^{2}=0.97\right)$. As expected, salt and $\mathrm{S} / \mathrm{M}$ content of curd increased with higher salt concentration in the test solution (Table 4). The S/M content of curd immersed in the $60 \mathrm{~g} / \mathrm{L} \mathrm{NaCl}$ test solution for $6 \mathrm{~h}$ was $44 \mathrm{~g} / \mathrm{kg}$, which is within the normal range for Cheddar cheese in the United States (Agarwal et al., 2011).

Immersion with Different Ca Levels. When test solutions were prepared with undiluted whey, precipitation of calcium phosphate occurred after addition of more than $2 \mathrm{~g} / \mathrm{L} \mathrm{Ca}\left(\right.$ as $\mathrm{CaCl}_{2}$ ). This was prevented by diluting whey 1:1 with deionized water, which allowed

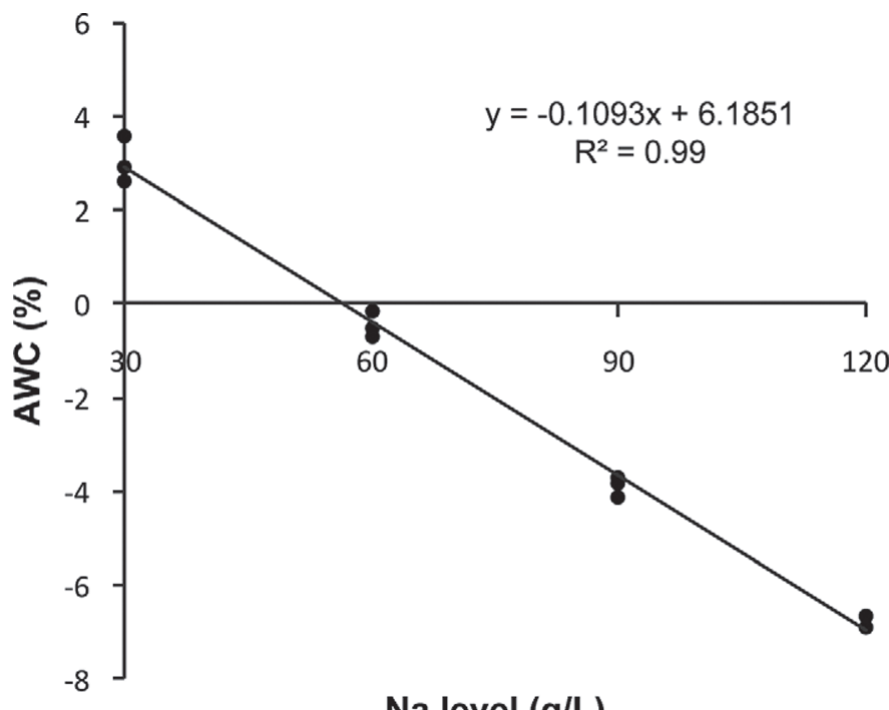

Na level (g/L)

Figure 5. Effect of brine salt concentration (with linear regression) on adjusted weight change (AWC) of cheese curd after a 6-h immersion at $22^{\circ} \mathrm{C}$ in whey-brine solutions (containing $6 \mathrm{~g} / \mathrm{L} \mathrm{Ca}$ ). up to $27 \mathrm{~g} / \mathrm{L} \mathrm{Ca}$ to be added without precipitation. Adding phosphate caused precipitation of calcium phosphate, even in diluted whey. Testing the curd response to high Ca levels was achieved by not adding any phosphate. Even so, as the Ca level increased, the test solutions became more turbid, presumably from some precipitation of $\mathrm{Ca}$ with phosphate already present in the whey. Thus, even though Ca was added at 1, 5, 10, and $20 \mathrm{~g} / \mathrm{L}$, the concentration of soluble Ca in the test solutions was $1.2,4.7,8.3$, and $15.4 \mathrm{~g} / \mathrm{L}$, respectively.

When salted Cheddar curd (composition shown in Table 5) was immersed in test solutions containing different Ca levels, both Ca level $(P<0.001)$ and immersion time $(P=0.004)$ significantly affected cheese moisture. Moisture increased significantly after immersion at test solutions of 1,5 , and $10 \mathrm{~g} / \mathrm{L} \mathrm{Ca}$, indicating a swelling of the curd particles with a concomitant absorption of moisture into the curd (Table 6). Cheese moisture decreased with higher Ca levels $\left(\mathrm{R}^{2}=0.89\right.$, pooled over immersion time). A similar occurrence of decreased curd moisture in brines of increasing Ca levels was shown by Fucà et al. (2012). Curd immersed in $20 \mathrm{~g} / \mathrm{L}$ Ca test solution did not change in moisture after $6 \mathrm{~h}$ and then decreased slightly after $18 \mathrm{~h}$.

Table 5. Cheddar curd composition before immersion in test solutions containing $1,5,10$, or $20 \mathrm{~g} / \mathrm{L}$ of added $\mathrm{Ca}$ and $15 \mathrm{~g} / \mathrm{L}$ of added sodium

\begin{tabular}{lc}
\hline Variable $^{1}$ & Mean \\
\hline Moisture (g/kg of cheese) & 405 \\
$\mathrm{pH}$ & 5.4 \\
$\mathrm{Na}(\mathrm{g} / \mathrm{kg}$ of cheese) & 6.2 \\
$\mathrm{Na} / \mathrm{M}(\mathrm{g} / \mathrm{kg})$ & 15.1 \\
Total Ca $(\mathrm{g} / \mathrm{kg}$ of cheese) & 6.9 \\
Serum $\mathrm{Ca}(\mathrm{g} / \mathrm{kg}$ of serum) & 4.0 \\
Insoluble Ca (g/kg of cheese) & 5.2 \\
Insol Ca/solids (g/kg of solids) & 8.8 \\
\hline
\end{tabular}

${ }^{1} \mathrm{Na} / \mathrm{M}=\mathrm{Na}$ in moisture $=\mathrm{Na} /(\mathrm{Na}+$ moisture $)$; insoluble $\mathrm{Ca}=$ total $\mathrm{Ca}-$ serum $\mathrm{Ca}$; Insol Ca/solids $=$ insoluble $\mathrm{Ca} \times 1,000 /(1,000$ - moisture). 
Table 6. Mean moisture, $\mathrm{Na}, \mathrm{Na} / \mathrm{M}^{1}, \mathrm{pH}$, and weight change of Cheddar cheese curd after immersion in whey test solutions containing $1,5,10$, or $20 \mathrm{~g} / \mathrm{L}$ of added $\mathrm{Ca}$ and $15 \mathrm{~g} / \mathrm{L}$ of added $\mathrm{Na}$

\begin{tabular}{|c|c|c|c|c|}
\hline \multirow[b]{2}{*}{ Variable } & \multicolumn{4}{|c|}{ Added Ca (g/L) } \\
\hline & 1 & 5 & 10 & 20 \\
\hline \multicolumn{5}{|l|}{ After $6 \mathrm{~h}$} \\
\hline Moisture (g/kg of cheese) & $455^{\mathrm{f} *}$ & $437^{\mathrm{e} *}$ & $423^{\mathrm{cd} *}$ & $409^{\mathrm{b}}$ \\
\hline $\mathrm{Na}(\mathrm{g} / \mathrm{kg}$ of cheese $)$ & $6.56^{\mathrm{b} *}$ & $6.47^{\mathrm{ab}}$ & $6.48^{\mathrm{ab} *}$ & $6.59^{\mathrm{b} *}$ \\
\hline $\mathrm{Na} / \mathrm{M}(\mathrm{g} / \mathrm{kg})$ & $14.2^{\mathrm{a} *}$ & $14.6^{\mathrm{ab}}$ & $15.1^{\mathrm{abc}}$ & $15.9^{\mathrm{c}}$ \\
\hline $\mathrm{pH}$ & $5.27^{\mathrm{d}}$ & $5.17^{\mathrm{c} *}$ & $5.05^{\mathrm{b} *}$ & $4.95^{\mathrm{a} *}$ \\
\hline Weight change (\%) & $8.9^{\mathrm{f} *}$ & $5.0^{\mathrm{d} *}$ & $3.1^{\mathrm{c} *}$ & $1.4^{\mathrm{b} *}$ \\
\hline \multicolumn{5}{|l|}{ After $18 \mathrm{~h}$} \\
\hline Moisture (g/kg of cheese) & $458^{\mathrm{f} *}$ & $433^{\mathrm{de} *}$ & $418^{\mathrm{bc} *}$ & $395^{\mathrm{a} *}$ \\
\hline $\mathrm{Na}(\mathrm{g} / \mathrm{kg}$ of cheese $)$ & $7.17^{\mathrm{c} *}$ & $6.53^{\mathrm{b}}$ & $6.30^{\mathrm{ab}}$ & $6.09^{\mathrm{a}}$ \\
\hline $\mathrm{Na} / \mathrm{M}(\mathrm{g} / \mathrm{kg})$ & $15.4^{\mathrm{bc}}$ & $14.9^{\mathrm{ab}}$ & $14.9^{\mathrm{ab}}$ & $15.2^{\mathrm{bc}}$ \\
\hline $\mathrm{pH}$ & $5.32^{\mathrm{d}}$ & $5.14^{\mathrm{c} *}$ & $5.06^{\mathrm{b} *}$ & $4.90^{\mathrm{a} *}$ \\
\hline Weight change (\%) & $9.8^{\mathrm{e} *}$ & $3.7^{\mathrm{c} *}$ & $1.7^{\mathrm{b} *}$ & $-0.5^{\mathrm{a} *}$ \\
\hline
\end{tabular}

Calcium content of the test solutions significantly influenced all aspects of $\mathrm{Ca}(P<0.001)$ in cheese. Immersion time was a significant factor on serum and total Ca levels $(P<0.001)$ but did not significantly affect insoluble $\mathrm{Ca}(P=0.620)$ or Insol $\mathrm{Ca} /$ solids $(P=1)$. As expected, both total $\mathrm{Ca}\left(\mathrm{R}^{2}=0.95\right)$ and serum $\mathrm{Ca}$ $\left(\mathrm{R}^{2}=0.84\right)$ increased proportionally with increasing $\mathrm{Ca}$ level in test solution. After immersion of curd in a solution of $10 \mathrm{~g} / \mathrm{L} \mathrm{Ca}$, the level of serum Ca increased but the Insol $\mathrm{Ca}$ /solids ratio did not change significantly (Table 7), indicating that insoluble Ca levels in curd solids were unchanged. However, in the $20 \mathrm{~g} / \mathrm{L}$ Ca solution, the Insol Ca/solids ratio increased from $8.8 \mathrm{~g} / \mathrm{kg}$ before immersion to $10.0 \mathrm{~g} / \mathrm{kg}$ after the 6 -h immersion and to $9.7 \mathrm{~g} / \mathrm{kg}$ after the $18-\mathrm{h}$ immersion.

Both $\mathrm{Na}$ and Na-in-moisture $(\mathbf{N a} / \mathbf{M})$ were significantly affected by Ca content of test solution $(P<0.001$ and $P=0.003$, respectively $), \mathrm{Ca} \times$ time interaction $(P$
$<0.001$ and $P=0.001$, respectively), but not by the immersion time $(P=0.946$ and $P=0.373$, respectively). Although, after the 6-h immersion, we detected a trend of increasing $\mathrm{Na} / \mathrm{M}$ in test solutions of higher $\mathrm{Ca}$ levels, no significant difference in $\mathrm{Na} / \mathrm{M}$ occurred with continued immersion until $18 \mathrm{~h}$ (Table 6). This indicates that $\mathrm{Na}^{+}$diffuses slower than water within 6 $\mathrm{h}$ and reaches equilibrium after $18 \mathrm{~h}$ of immersion.

During cheese manufacture, the curd was milled at $\mathrm{pH} 5.40$, and then salted over a 20-min period; just before immersion, the curd $\mathrm{pH}$ was 5.3. The $\mathrm{pH}$ of curd after immersion was significantly affected by the $\mathrm{Ca}$ content of test solution and $\mathrm{Ca} \times$ time interaction $(P$ $<0.001$ and $P=0.005)$ but not by the immersion time $(P=0.561)$. As the Ca level in solution increased, $\mathrm{pH}$ of curd decreased proportionally $\left(\mathrm{R}^{2}=0.92\right.$, pooled over immersion time), with the $\mathrm{pH}$ of curd immersed in $20 \mathrm{~g} / \mathrm{L} \mathrm{Ca}$ solution for $18 \mathrm{~h}$ decreasing to 4.9 (Table

Table 7. Mean total Ca, serum Ca, insoluble $\mathrm{Ca}$, and insoluble $\mathrm{Ca} /$ solids (Insol Ca/solids) of Cheddar cheese curd after immersion in whey test solutions containing $1,5,10$, or $20 \mathrm{~g} / \mathrm{L}$ of added $\mathrm{Ca}$ and $15 \mathrm{~g} / \mathrm{L}$ of added $\mathrm{Na}$

\begin{tabular}{lllcc}
\hline & \multicolumn{4}{c}{ Added Ca $(\mathrm{g} / \mathrm{L})$} \\
\cline { 2 - 4 } Variable & 1 & 5 & 10 & 20 \\
\hline After 6 h & & & \\
Total Ca (g/kg of cheese) & $5.9^{\mathrm{a} *}$ & $7.4^{\mathrm{b} *}$ & $9.0^{\mathrm{c} *}$ & $11.6^{\mathrm{d} *}$ \\
Serum Ca (g/kg of serum) & $3.6^{\mathrm{a}}$ & $5.2^{\mathrm{b} *}$ & $7.6^{\mathrm{c}}$ & $11.5^{\mathrm{d} *}$ \\
Insoluble Ca (g/kg of cheese) & $4.1^{\mathrm{a} *}$ & $4.7^{\mathrm{ab} *}$ & $5.2^{\mathrm{bc}}$ & $5.9^{\mathrm{c}}$ \\
Insol Ca/solids (g/kg solids) & $7.5^{\mathrm{a} *}$ & $8.4^{\mathrm{ab}}$ & $9.1^{\mathrm{bc}}$ & $10.0^{\mathrm{c}}$ \\
After 18 h & & & & \\
Total Ca (g/kg of cheese) & $5.6^{\mathrm{a} *}$ & $7.8^{\mathrm{b} *}$ & $9.8^{\mathrm{c} *}$ & $13.2^{\mathrm{e} *}$ \\
Serum Ca (g/kg of serum) & $3.4^{\mathrm{a} *}$ & $6.9^{\mathrm{c} *}$ & $10.8^{\mathrm{d} *}$ & $18.0^{\mathrm{e}^{*}}$ \\
Insoluble Ca (g/kg of cheese) & $4.1^{\mathrm{a} *}$ & $4.8^{\mathrm{ab} *}$ & $5.4^{\mathrm{bc}}$ & $5.9^{\mathrm{c}}$ \\
Insol Ca/solids (g/kg of solids) & $7.5^{\mathrm{a} *}$ & $8.5^{\mathrm{ab}}$ & $9.3^{\mathrm{bc}}$ & $9.7^{7^{\mathrm{bc}}}$ \\
\hline
\end{tabular}

${ }^{\mathrm{a} e}$ Means within rows with the same letter were not significantly different, $\alpha=0.05$.

*Means were significantly different from Cheddar cheese curd before immersion, $\alpha=0.05$. 
6). Similar effects were reported by Pastorino et al. (2003b), who reported the $\mathrm{pH}$ decrease in cheese after injection of $\mathrm{CaCl}_{2}$ solution. Part of the $\mathrm{pH}$ decrease during the 18-h immersion can be attributed to continued fermentation of lactose by starter bacteria (as occurs during pressing), although for the curd used in this experiment, the $\mathrm{pH}$ after $18 \mathrm{~h}$ of pressing was $\sim 5.1$ to 5.2 , so part of the $\mathrm{pH}$ decrease during immersion in test solutions can be attributed to absorption of $\mathrm{Ca}$ into the cheese curd and the $\mathrm{pH}$ decrease that occurs when calcium phosphate precipitates.

Weight of curd $(P<0.001)$ was significantly affected by $\mathrm{Ca}$ content of the test solution, immersion time, and $\mathrm{Ca} \times$ time interaction. When pooled over immersion time, weight increase $\left(\mathrm{R}^{2}=0.77\right)$ and insoluble Ca/solids $\left(\mathrm{R}^{2}=0.76\right.$, Figure 6$)$ were positively and inversely proportional to the Ca level in test solution, respectively. After $6 \mathrm{~h}$ of immersion, all curd pieces gained weight with greatest weight change of $8.9 \%$ occurring with lowest Ca content of $1 \mathrm{~g} / \mathrm{L}$ (Table 6). With continued immersion for $18 \mathrm{~h}$, curd in $1 \mathrm{~g} / \mathrm{L}$ Ca test solution continued to gain weight with a final weight increase of $9.8 \%$, whereas those with higher $\mathrm{Ca}$ solutions lost weight between 6 and $18 \mathrm{~h}$ (Figure 7). Curd in $20 \mathrm{~g} / \mathrm{L}$ Ca solution had a net $0.5 \%$ loss of weight compared with curd before immersion.

\section{DISCUSSION}

When salt is applied to curd, a portion of salt is dissolved in moisture located on and slightly within the curd surface, potentially reaching a saturated solution when sufficient salt is applied. It is generally considered that movement of water from the curd interior to the surface occurs because of osmosis (Guerts et al., 1974; Guinee, 2004; Guinee and Fox, 2004). Such outward movement of water in response to osmotic pressure is usually concomitant with inward diffusion of sodium and chloride ions from dissolved salt. A salt concentration gradient develops, with high $\mathrm{S} / \mathrm{M}$ at the curd surface, decreasing $\mathrm{S} / \mathrm{M}$ within the curd pieces, and very low $\mathrm{S} / \mathrm{M}$ at the center. Such a salt gradient, however, needs to be considered in relation to salting-in effects at low $\mathrm{S} / \mathrm{M}$ and salting-out effects at high $\mathrm{S} / \mathrm{M}$. At low S/M $(\sim 0.5 \%)$, curd protein solubility increases, whereas at high $\mathrm{S} / \mathrm{M}$, protein solubility decreases, causing dehydration and contraction of the curd protein matrix (Paulson et al., 1998; Guinee and Fox, 2004; McMahon et al., 2005). Thus, it can be expected that the curd interior with low $\mathrm{S} / \mathrm{M}$ (curd volume A as shown in Figure 8 ) would have a tendency to expand and hold water, whereas the curd exterior and surface (curd volume B in Figure 8) with its high S/M would tend to contract and expel water (Fucà et al., 2012).

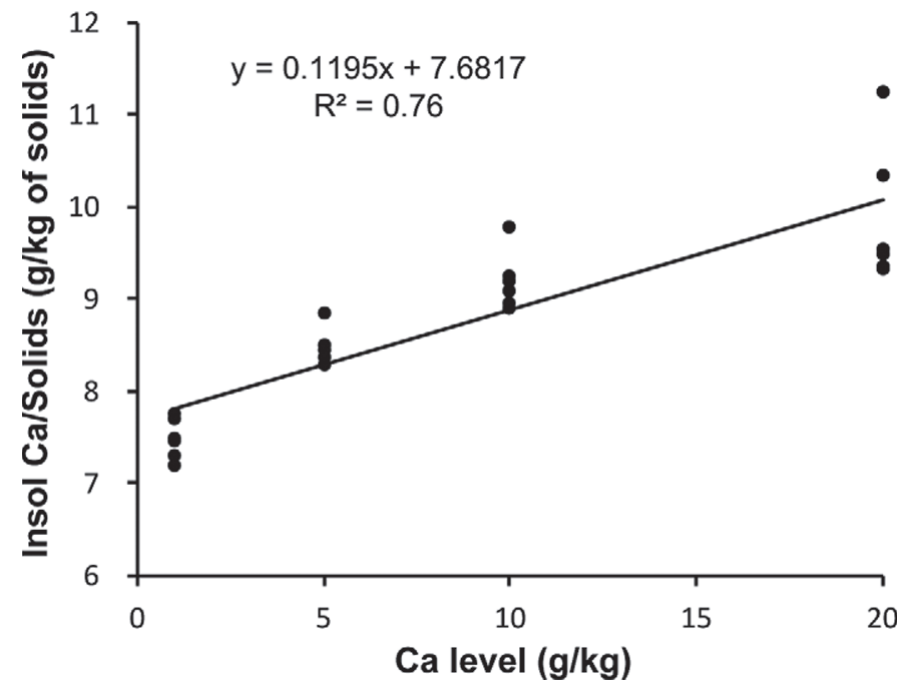

Figure 6. Effect of Ca concentration (with linear regression) on insoluble $\mathrm{Ca}$ /solids (Insol Ca/Solids) of cheese curd after 6- and 18-h immersions (pooled data) at $22^{\circ} \mathrm{C}$ in whey-brine solutions (containing $13.1 \pm 1.2 \mathrm{~g} / \mathrm{kg}$ of $\mathrm{Na})$.

At the beginning of salting, the ratio of volumes between exterior $(\mathrm{B}$, high $\mathrm{S} / \mathrm{M})$ and interior (A, low $\mathrm{S} / \mathrm{M}$ ) curd portions was relatively small. Therefore, the chemical environment surrounding the curd matrix was dominated by low S/M. Such curd would retain moisture with very little whey expulsion occurring, even as salt diffuses into the curd interior. As salting continues, the $\mathrm{S} / \mathrm{M}$ concentration throughout the curd volume increases as more salt is added and further time allowed for salt diffusion into curd particles. The portion of the curd volume with high $\mathrm{S} / \mathrm{M}$ increases and, when there

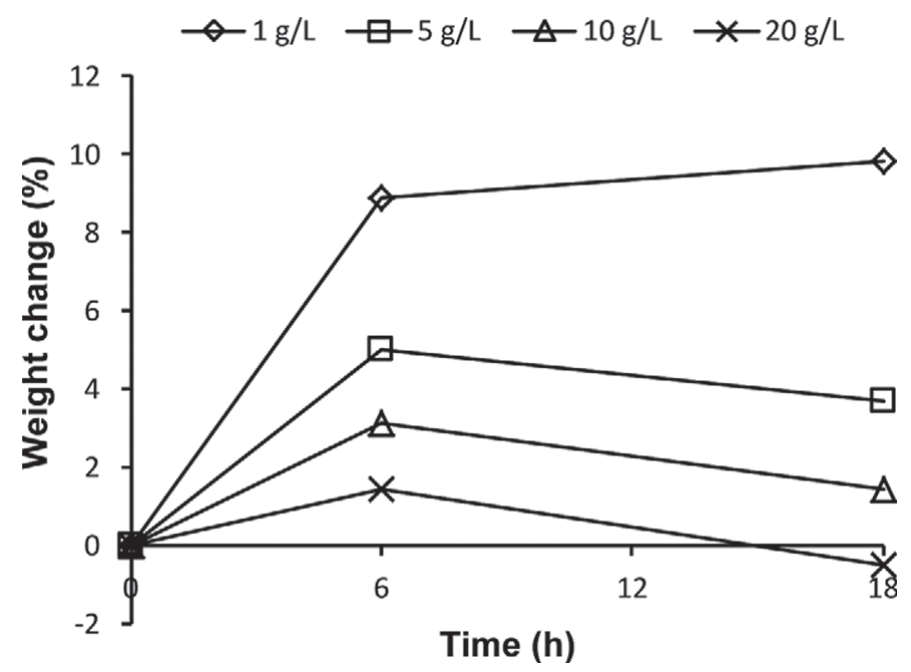

Figure 7. Curd weight change over time after 6- and 18-h immersions (pooled data) at $22^{\circ} \mathrm{C}$ in whey-brine solutions (containing $1,5,10$ and $20 \mathrm{~g} / \mathrm{L}$ of added $\mathrm{Ca}$ and $13.1 \pm 1.2 \mathrm{~g} / \mathrm{kg}$ of sodium). 


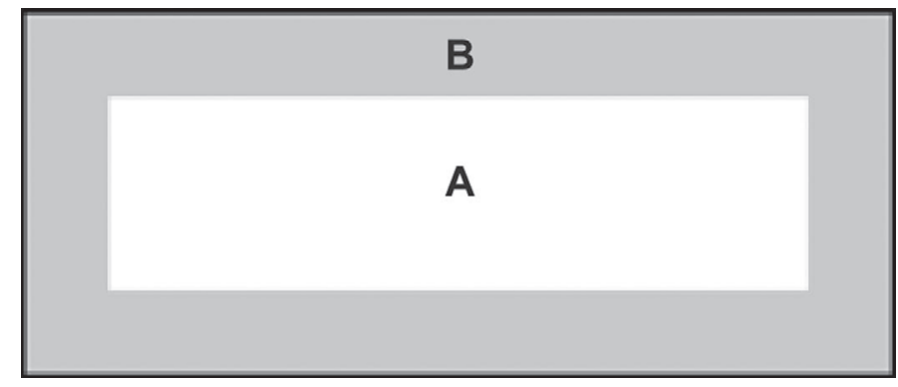

Figure 8. Schematic cross section of a curd particle showing (A) the central interior portion with low salt-in-moisture concentration, and (B) the surface exterior portion that has high salt-in-moisture concentration.

is sufficient volume that has high $\mathrm{S} / \mathrm{M}$, a salting-out effect occurs, the protein matrix contracts, and whey is expelled from the curd.

Although salting using 5-min and 10-min intervals produced similar overall whey expulsion, we observed a difference in the rate of whey expulsion. Some whey expulsion occurred after the second application of salt and then a flush of whey expulsion occurred after the third application. With the shorter time interval, there was insufficient time for much salt diffusion into the interior volume of the curd, whereas there was a high concentration in the exterior volume. This high B:A salt ratio promotes rapid shrinkage of the curd exterior and most of the whey is expelled within the subsequent $10 \mathrm{~min}$. An equilibrium appears to be reached between the salt-induced osmotic movement of water molecules and the protein network response to salt so that whey expulsion virtually ceases until an external force is applied during pressing.

Using a 10-min salting interval allows more time for salt to diffuse into the curd interior so that the B:A salt ratio is lower than with the 5 -min salting intervals. A flush of whey is expelled after the third application of salt but then the rate slows down and whey expulsion continues for $20 \mathrm{~min}$ or more. Having a faster whey expulsion could cause more salt to be lost from the curd exterior but these different rates of whey expulsion had no overall effect on the final composition of the cheese. Where it may be of concern is in the post-salting manufacturing steps because the expelled whey would help lubricate the curd pieces and prevent sticking to surfaces of equipment such as a cheddaring tower.

When salting was decreased from 30 to 25 or $20 \mathrm{~g} /$ $\mathrm{kg}$, the B:A salt ratio was lowered. With lower salt concentration, the protein matrix remained more hydrated and there was a reduced driving force to cause shrinkage. Hence, less whey expulsion occurred. This agrees with Fucà et al. (2012) in brined cheese and Pastorino et al. (2003a) in cheese injected with salt solutions. With $20 \mathrm{~g} / \mathrm{kg}$ salting using only 1 salt application, we observed only minimal whey expulsion $(\leq 5$ $\mathrm{g} / \mathrm{kg}$ ). Adding salt slowly (with 3 applications) did not produce a significant B:A salt ratio to induce protein matrix contraction, and whey expulsion was probably just a result of osmotic forces. Adding salt more quickly allowed a faster increase in salt concentration in the exterior portion, which would induce expulsion of slightly more whey. No advantage was gained by adding the salt all at once as the rapid increase in B:A salt ratio contracted the exterior protein network, causing a flow of whey expulsion that took with it some of the salt. Therefore, achieving even a $33 \%$ reduction in sodium content of cheese and retaining whey expulsion properties requires that $\mathrm{KCl}$ be used to maintain the curd shrinkage and allow syneresis.

When cheese curd is immersed in solutions of different salt levels, weight change is related to diffusion of both $\mathrm{NaCl}$ and moisture in or out of the cheese. Adjusted weight change that takes into account the mass of salt absorbed into the curd provides an indication of contraction or expansion of the protein matrix based on the mass of water that is lost or gained. Such contraction and expansion is a function of protein solubility based on the chemical environment surrounding the protein matrix. Based on the crossover between curd expansion in $30 \mathrm{~g} / \mathrm{L}$ salt solution and curd shrinkage in $90 \mathrm{~g} / \mathrm{L}$ salt solution (Figure 5), we estimated that a salt solution of $\sim 57 \mathrm{~g} / \mathrm{L}$ would cause no change in AWC. If the only driving force for whey expulsion were osmotic pressure, such curd would be expected to lose moisture and shrink. At a lower salt level (i.e., $30 \mathrm{~g} / \mathrm{L}$ ), both curd weight and AWC increased due to water absorption in response to a salting-in effect of protein matrix. At salt levels of 90 and $120 \mathrm{~g} / \mathrm{L}$, salting-out effects promoted protein matrix contraction and concomitant syneresis greater than the mass of salt absorbed so that both cheese weight and AWC decreased during the 6-h immersion (Table 4). Similar results have been reported in brined cheeses (McMahon et al., 2009; Fucà et al., 2012).

The Ca content of test solutions had a more obvious effect on contraction or expansion of the curd protein matrix, as shown by greater weight gain through water absorption, when less calcium is bound to the protein matrix (Figure 9). At lower Ca concentrations (i.e., 1 and $5 \mathrm{~g} / \mathrm{L}$ ), dissolution of insoluble Ca (i.e., Ca bound to protein) increased protein solubility. As the protein matrix became more hydrated, it expanded as water infused into the curd. At higher Ca concentrations (i.e., 10 and $20 \mathrm{~g} / \mathrm{L}$ ), protein-bound Ca increased, resulting in a more cross-linked and rigid protein matrix. Binding of Ca to proteins occurred more slowly than diffusion and so an initial weight gain occurred during the first 


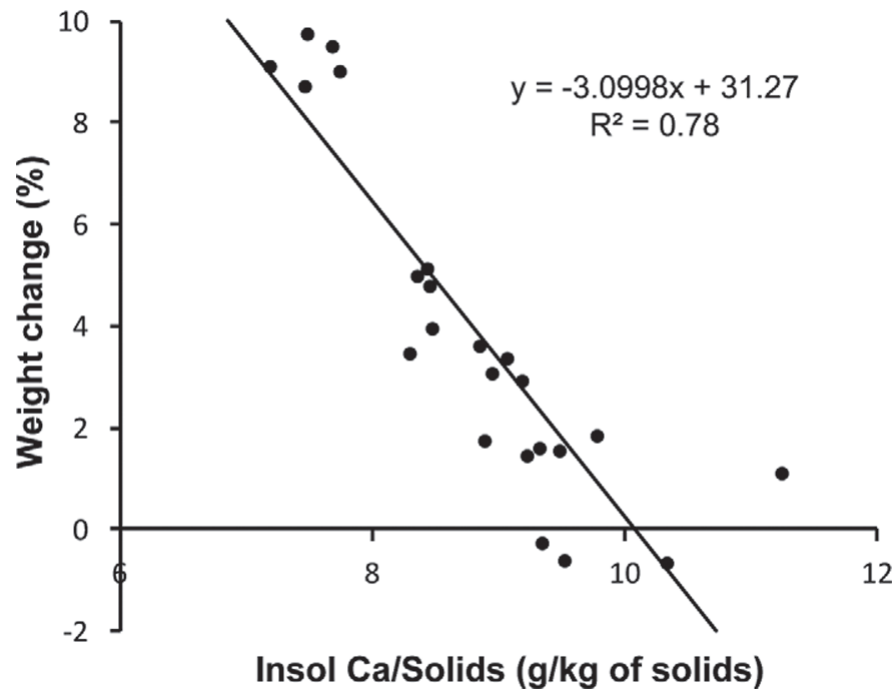

Figure 9. Cheese weight change (\%) as a function of insoluble $\mathrm{Ca} /$ solids (Insol Ca/Solids) after 6- and 18-h immersions at $22^{\circ} \mathrm{C}$ (pooled data) in whey-brine solutions (containing 1, 5, 10, and $20 \mathrm{~g} / \mathrm{L}$ of added $\mathrm{Ca}$ and $13.1 \pm 1.2 \mathrm{~g} / \mathrm{kg}$ of sodium).

$6 \mathrm{~h}$, followed by a decrease in weight between 6 and 18 $\mathrm{h}$ (Figure 7). The importance of calcium in controlling the protein matrix in cheese has been reported previously (Pastorino et al., 2003b; McMahon et al., 2005, 2009; Fucà et al., 2012).

\section{CONCLUSIONS}

Salt affects curd syneresis by combined driving forces of osmotic movement of water molecules in response to the presence of a salt gradient, and contraction or expansion of the curd protein network in response to salt concentration. At low S/M, curd protein solubility increased and caused protein matrix expansion, whereas at high S/M, protein solubility decreased, resulting in dehydration and contraction of curd protein matrix. Increasing the salting interval to $10 \mathrm{~min}$ slowed the expulsion of whey without affecting final cheese composition. The delayed expressed whey may help lubricate the curd and prevent it from sticking on surfaces of equipment. A $33 \%$ substitution of $\mathrm{NaCl}$ with $\mathrm{KCl}$ can help to restore syneresis properties of reducedsodium cheese curd. Understanding the effect of salting on whey expulsion before and during pressing can help in designing process systems for manufacture of cheeses with reduced sodium content.

\section{ACKNOWLEDGMENTS}

The authors thank Doug Palmer from the Aggie Creamery (Utah State University, Logan) for cheese manufacture, which was performed as part of the cheese applications program of the Western Dairy Center. This research was supported by the Utah Agricultural Experiment Station, Utah State University, and approved as journal paper number 8695. The use of trade names in this publication does not imply endorsement by the Utah State University of the products named nor criticism of similar ones not mentioned.

\section{REFERENCES}

Agarwal, S., D. McCoy, W. Graves, P. D. Gerard, and S. Clark. 2011. Sodium content in retail Cheddar, Mozzarella, and process cheeses varies considerably in the United States. J. Dairy Sci. 94:16051615.

Agarwal, S., J. R. Powers, B. G. Swanson, S. Chen, and S. Clark. 2008. Influence of salt-to-moisture ratio on starter culture and calcium lactate crystal formation. J. Dairy Sci. 91:2967-2980.

Ayyash, M. M., F. Sherkat, P. Francis, R. P. W. Williams, and N. P. Shah. 2011. The effect of sodium chloride substitution with potassium chloride on texture profile and microstructure of Halloumi cheese. J. Dairy Sci. 94:37-42.

Daviau, C., M. H. Famelart, A. Pierre, H. Goudédranche, and J. L. Maubois. 2000. Rennet coagulation of skim milk and curd drainage: Effect of $\mathrm{pH}$, casein concentration, ionic strength and heat treatment. Lait 80:397-415.

Dejmek, P., and P. Walstra. 2004. The syneresis of rennet-coagulated curd. Pages 71-103 in Cheese: Chemistry, Physics and Microbiology. Vol. 1. P. L. H. McSweeney, P. F. Fox, T. M. Cogan, and T. P. Guinee, ed. Elsevier Ltd., London, UK.

Everard, C. D., D. J. O'Callaghan, M. J. Mateo, C. P. O'Donnell, M. Castillo, and F. A. Payne. 2008. Effects of cutting intensity and stirring speed on syneresis and curd losses during cheese manufacture. J. Dairy Sci. 91:2575-2582.

Fagan, C. C., M. Castillo, F. A. Payne, C. P. O'Donnell, M. Leedy, and D. J. O'Callaghan. 2007. Novel online sensor technology for continuous monitoring of milk coagulation and whey separation in cheesemaking. J. Agric. Food Chem. 55:8836-8844.

Fitzgerald, E., and J. Buckley. 1985. Effect of total and partial substitution of sodium chloride on the quality of Cheddar cheese. J. Dairy Sci. 68:3127-3134.

Fox, P. F., T. P. Guinee, T. M. Cogan, and P. L. H. McSweeney. 2000. Salting of cheese curd. Pages 153-168 in Fundamentals of Cheese Science. Aspen Publishers Inc., Gaithersburg, MD.

Fucà, N., D. J. McMahon, M. Caccamo, L. Tuminello, S. La Terra, M. Manenti, and G. Licitra. 2012. Effect of brine composition and brining temperature on cheese physical properties in Ragusano cheese. J. Dairy Sci. 95:460-470.

Geng, X. L., F. W. J. van den Berg, A. N. Bager, and R. Ipsen. 2011. Dynamic visualization and microstructure of syneresis of cheese curd during mechanical treatment. Int. Dairy J. 21:711-717.

Georgakis, S. A. 1973. Studies on the manufacture of Greek Feta pickled cheese. I. Relation between the amount of salt used and duration of salting. Milchwissenschaft 28:500-502.

Grummer, J., N. Bobowski, M. Karalus, Z. Vickers, and T. Schoenfuss. 2013. Use of potassium chloride and flavor enhancers in low sodium Cheddar cheese. J. Dairy Sci. 96:1401-1418.

Grummer, J., M. Karalus, K. Zhang, Z. Vickers, and T. C. Schoenfuss. 2012. Manufacture of reduced-sodium Cheddar-style cheese with mineral salt replacers. J. Dairy Sci. 95:2830-2839.

Guerts, T. J., P. Walstra, and H. Mulder. 1974. Transport of salt and water during salting of cheese. 1. Analysis of the processes involved. Neth. Milk Dairy J. 28:102-129.

Guinee, T. P. 2004. Salting and the role of salt in cheese. Int. J. Dairy Technol. 57:99-109.

Guinee, T. P., and P. F. Fox. 2004. Salt in cheese: Physical, chemical and biological aspects. Pages 207-259 in Cheese: Chemical, Physics and Microbiology. Vol. 1. 3rd ed. P. L. H. McSweeney, P. F. Fox, T. M. Cogan, and T. P. Guinee, ed. Elsevier Ltd., London, UK. 
Guo, M. R., J. A. Gilmore, and P. S. Kindstedt. 1997. Effect of sodium chloride on the serum phase of Mozzarella cheese. J. Dairy Sci. 80:3092-3098.

Guo, M. R., and P. S. Kindstedt. 1995. Age-related changes in the water phase of Mozzarella cheese. J. Dairy Sci. 78:2099-2107.

Johnson, M. E., R. Kapoor, D. J. McMahon, D. R. McCoy, and R. G. Narasimmon. 2009. Reduction of sodium and fat levels in natural and processed cheeses: Scientific and technological aspects. Compr. Rev. Food Sci. Food Safety 8:252-268.

Katsiari, M. C., L. P. Voutsinas, E. Alichanidis, and I. G. Roussis. 1998. Manufacture of Kefalograviera cheese with less sodium by partial replacement of $\mathrm{NaCl}$ with $\mathrm{KCl}$. Food Chem. 61:63-70.

Kindstedt, P. S., L. J. Kiely, and J. A. Gilmore. 1992. Variation in composition and functional properties within brine-salted Mozzarella cheese. J. Dairy Sci. 75:2913-2921.

Lindsay, R. C., S. M. Hargett, and C. S. Bush. 1982. Effect of sodium/ potassium (1:1) chloride and low sodium chloride concentrations on quality of Cheddar cheese. J. Dairy Sci. 65:360-370.

McMahon, D. J., M. M. Motawee, and W. R. McManus. 2009. Influence of brine concentration and temperature on composition, microstructure, and yield of feta cheese. J. Dairy Sci. 92:4169-4179.

McMahon, D. J., C. J. Oberg, M. A. Drake, N. Farkye, L. V. Moyes, M. R. Arnold, B. Ganesan, J. Steele, and J. R. Broadbent. 2014. Impact of sodium, potassium, magnesium, and calcium salt cations on $\mathrm{pH}$, proteolysis, organic acids, and microbial populations during storage of full fat Cheddar cheese. J. Dairy Sci. 97. In press.
McMahon, D. J., B. Paulson, and C. J. Oberg. 2005. Influence of calcium, $\mathrm{pH}$, and moisture on protein matrix structure and functionality in direct-acidified nonfat Mozzarella cheese. J. Dairy Sci. 88:3754-3763.

Pastorino, A. J., C. L. Hansen, and D. J. McMahon. 2003a. Effect of salt on structure-function relationships of cheese. J. Dairy Sci. 86:60-69.

Pastorino, A. J., N. P. Ricks, C. L. Hansen, and D. J. McMahon. 2003b. Effect of calcium and water injection on structure-function relationships of cheese. J. Dairy Sci. 86:105-113.

Paulson, B. M., D. J. McMahon, and C. J. Oberg. 1998. Influence of sodium chloride on appearance, functionality, and protein arrangements in nonfat Mozzarella cheese. J. Dairy Sci. 81:2053-2064.

Pearse, M. J., and A. G. Mackinlay. 1989. Biochemical aspects of syneresis: A review. J. Dairy Sci. 72:1401-1407.

Resmini, P., G. Volonterio, S. Annibaldi, and G. Ferri. 1974. Study of salt diffusion in Parmigiano-Reggiano cheese using $\mathrm{Na}^{36} \mathrm{Cl}$. Sci. Tecn. Latt. Cas. 25:149-166.

Rogers, N. R., D. J. McMahon, C. R. Daubert, T. K. Berry, and E. A. Foegeding. 2010. Rheological properties and microstructure of Cheddar cheese made with different fat contents. J. Dairy Sci. 93:4565-4576. http://dx.doi.org/10.3168/jds.2010-3494.

Schroeder, C. L., F. W. Bodyfelt, C. J. Wyatt, and M. R. McDaniel. 1988. Reduction of sodium chloride in Cheddar cheese: Effect on sensory, microbiological, and chemical properties. J. Dairy Sci. 71:2010-2020 